\title{
Systems metabolic engineering
} of Corynebacterium glutamicum for the production of the carbon-5 platform chemicals 5 -aminovalerate and glutarate

\author{
Christina Maria Rohles, Gideon Gießelmann, Michael Kohlstedt, Christoph Wittmann and Judith Becker
}

\begin{abstract}
Background: The steadily growing world population and our ever luxurious life style, along with the simultaneously decreasing fossil resources has confronted modern society with the issue and need of finding renewable routes to accommodate for our demands. Shifting the production pipeline from raw oil to biomass requires efficient processes for numerous platform chemicals being produced with high yield, high titer and high productivity.
\end{abstract}

Results: In the present work, we established a de novo bio-based production process for the two carbon-5 platform chemicals 5-aminovalerate and glutarate on basis of the lysine-hyperproducing strain Corynebacterium glutamicum LYS-12. Upon heterologous implementation of the Pseudomonas putida genes davA, encoding 5-aminovaleramidase and $\operatorname{dav} B$, encoding lysine monooxygenase, 5-aminovalerate production was established. Related to the presence of endogenous genes coding for 5 -aminovalerate transaminase ( $\mathrm{gab} T$ ) and glutarate semialdehyde dehydrogenase, 5-aminovalerate was partially converted to glutarate. Moreover, residual L-lysine was secreted as by-product. The issue of by-product formation was then addressed by deletion of the lysE gene, encoding the L-lysine exporter. Additionally, a putative gabT gene was deleted to enhance 5 -aminovalerate production. To fully exploit the performance of the optimized strain, fed-batch fermentation was carried out producing $28 \mathrm{~g} \mathrm{~L}^{-1}$ 5-aminovalerate with a maximal spacetime yield of $0.9 \mathrm{~g} \mathrm{~L}^{-1} \mathrm{~h}^{-1}$.

Conclusions: The present study describes the construction of a recombinant microbial cell factory for the production of carbon-5 platform chemicals. Beyond a basic proof-of-concept, we were able to specifically increase the production flux of 5-aminovalerate thereby generating a strain with excellent production performance. Additional improvement can be expected by removal of remaining by-product formation and bottlenecks, associated to the terminal pathway, to generate a strain being applicable as centerpiece for a bio-based production of 5-aminovalerate.

Keywords: Bio-nylon, Synthetic biology, Metabolic engineering, Platform chemical, Lysine monooxygenase, Heterologous production, Bio-economy

\section{Background}

Today's petrochemical industry is challenged by the everincreasing demand for commodity chemicals, polymer materials and related compounds, which is additionally aggravated by the ever-decreasing accessibility of fossil

*Correspondence: judith.becker@uni-saarland.de Institute of Systems Biotechnology, Saarland University, Saarbrücken, Germany resources as base material [1]. Hence, substantial effort has been made for providing alternative "green" routes to produce platform chemicals through microbial fermentation processes. Compounds of interest comprise organic acids [2] such as succinate [3-5], lactate [6], and itaconic acid [7], diamines including putrescine $[8,9]$ and cadaverine [10-14] and diols [15-18], all being applicable as building blocks for bio-based plastics. In this regards, also 5-aminovalerate and glutarate are attractive 
carbon-5 building blocks for the production of nylon from renewable feedstocks $[19,20]$. By now, Escherichia coli has been in the focus of interest as platform for either de novo biosynthesis [19] of 5-aminovalerate and glutarate or for biotransformation [20-22] thereof from L-lysine. As 5-aminovalerate and glutarate are degradation products of the proteinogenic amino acid L-lysine, we choose the non-pathogenic Gram-positive soil bacterium Corynebacterium glutamicum, a well-established industrial L-lysine producer [1], as metabolic chassis for the production of these carbon- 5 platform chemicals. Beyond the excellent availability of genetic tools [23], and knowledge of its physiology and large-scale fermentation [24, 25], engineered C. glutamicum has only recently been established as centerpiece for the production of L-lysine-derived cadaverine within a pipeline towards the manufacturing of the fully bio-based polyamide PA5.10 [13]. In this work, the metabolic pathway from L-lysine towards 5 -aminovalerate was reconstituted by stable genome-based implementation of the Pseudomonas putida KT2440 genes $\operatorname{davB}$, encoding lysine monooxygenase, and $\operatorname{dav} A$, encoding 5-aminovaleramide amidase (Fig. 1) - a strategy previously established for E. coli [19, 21]. Glutarate production relied on an endogenous pathway (Fig. 1). Though experimentally shown [26], full and unambiguous annotation of the genes coding for the required enzymes 5-aminovalerate transaminase (GabT) and glutarate semialdehyde dehydrogenase (GabD) is missing so far (Fig. 1). We further engineered the basic producer by elimination of by-product formation and focusing the production flux towards 5 -aminovalerate. Production was subsequently benchmarked in fed-batch fermentation.

\section{Results}

Recombinant expression of the davBA genes establishes 5 -aminovalerate and glutarate production in $C$. glutamicum

Upon implementation of the P. putida genes davBA in the genome of $C$. glutamicum LYS-12, this L-lysine-hyper

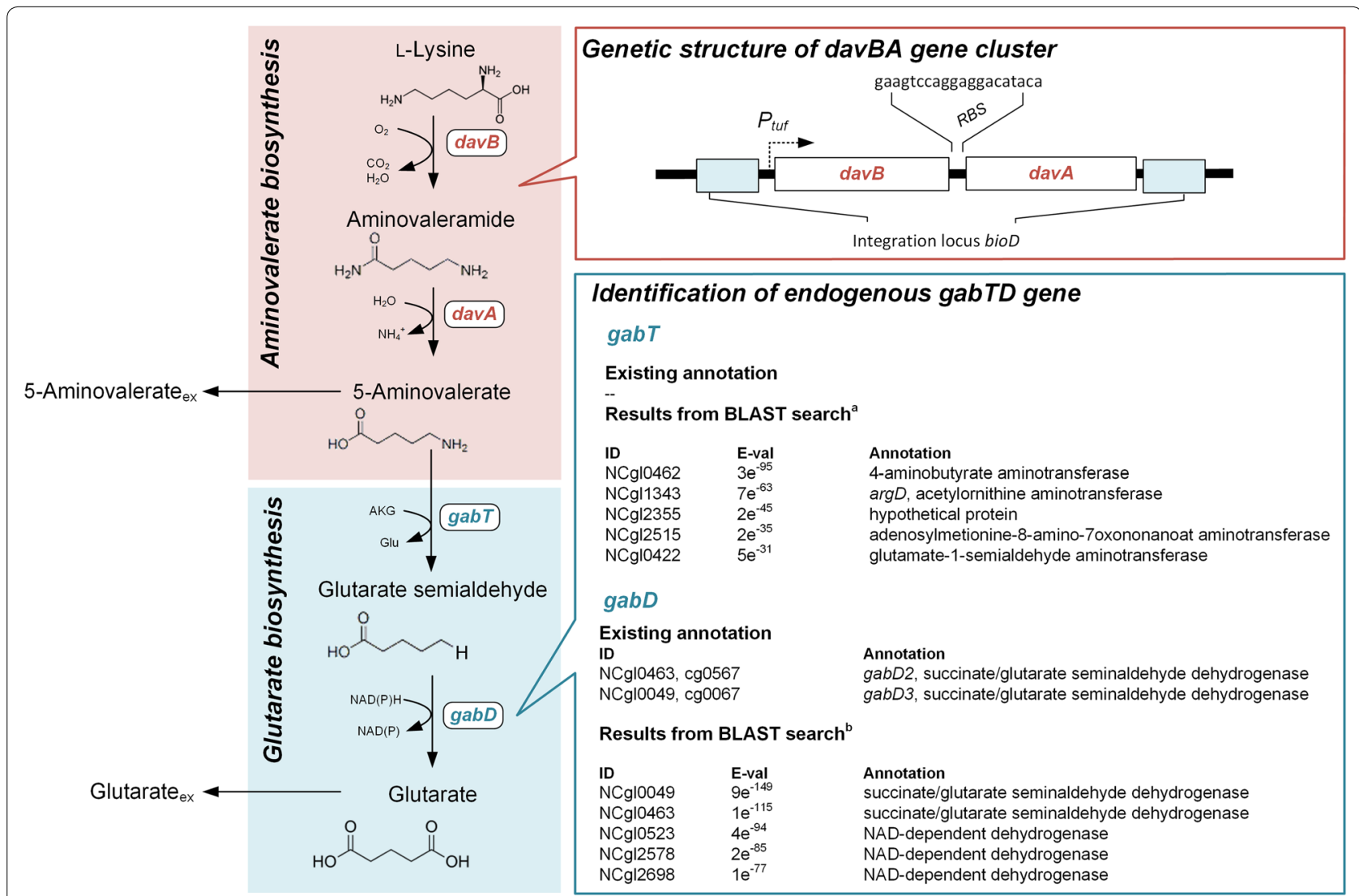

Fig. 1 Metabolic pathway design for the production of 5-aminovalerate and glutarate in Corynebacterium glutamicum starting from the pathway precursor L-lysine. Heterologous genes (davBA) from Pseudomonas putida KT2440 were used to reconstruct the 5-aminovalerate pathway comprising lysine monooxygenase (DavB) and 5-aminovaleramidase (DavA). Genes under control of the constitutive tuf-promotor were integrated in the bioD locus of the genome of C. glutamicum LYS-12. Glutarate production from 5-aminovalerate via the activity of 5-aminovalerate transaminase $(\mathrm{GabT})$ and glutarate semialdehyde dehydrogenase (GabD) relied on endogenous reaction with no or promiscuous gene annotation. Potential candidates were identified by BLASTX search using sequence information of the P. putida genes gabT (davT,PP_0213) and gabD (davD, PP_0214) ${ }^{b}$ 
producing strain was re-programmed for 5-aminovalerate and glutarate production. Genome-based integration of the construct (Fig. 1) was first verified by PCR analysis. Cloning-associated mutations were subsequently excluded by sequencing. Functional expression of lysine monooxygenase (DavB) and 5-aminovaleramidase (DavA) was validated by in vitro activity measurement. The underlying assay allowed parallel investigation of L-lysine consumption, related to DavB activity, and 5-aminovalerate production, related to DavA activity. In crude cell extracts of the recombinant AVA-1 strain both lysine consumption $\left(4.1 \pm 0.4 \mathrm{mmol} \mathrm{L}^{-1} \mathrm{~h}^{-1}\right)$ and 5 -aminovalerate production $\left(1.8 \pm 0.6 \mathrm{mmol} \mathrm{L}^{-1} \mathrm{~h}^{-1}\right)$ was observed. As no conversion took place in the parent strain C. glutamicum LYS-12, this could be specifically attributed to the heterologous $\operatorname{dav} B A$ expression. Additional proof for the functional operation of the pathway came from cultivation experiments. During growth of C. glutamicum AVA-1 in glucose minimal medium, both 5 -aminovalerate and glutarate were produced and secreted into the medium (Fig. 2a). The production was growth-associated. After depletion of glucose, 5-aminovalerate and glutarate accumulation stopped at a titer of 5.4 and $6.5 \mathrm{mM}$, identifying glutarate as major product in the AVA-1 strain. The pathway precursor L-lysine was also found in the culture supernatant, though it was only secreted to a lower extent of $2.9 \mathrm{mM}$ (Fig. 2a). All products were produced constantly and we could not observe any production shift throughout the cultivation (Fig. 2b), which allowed precise and representative determination of the yields (Table 1). Glutarate was produced most efficiently $\left(123 \mathrm{mmol} \mathrm{mol}^{-1}\right)$. In comparison, the 5 -aminovalerate yield was $24 \%$ lower and L-lysine secretion only contributed to about $19 \%$ of the total product formation. The observed production pattern indicated that the L-lysine exporter protein LysE obviously competed with the activity of lysine monooxygenase, catalyzing the initial step of the 5-aminovalerate/glutarate pathway. Similarly, 5-aminovalerate export competed with the endogenous transamination reaction (Fig. 1). The preference of the cell to rather form glutarate than 5-aminovalerate indicated that transamination was more efficient than export. However, once secreted, 5-aminovalerate was not channeled back into the glutarate pathway. Indeed, when C. glutamicum LYS-12 was grown in the presence of 5-aminovalerate, the concentration of 5-aminovalerate did not decrease over the cultivation time and no glutarate formation was observed.

\section{Secretion of the by-production L-lysine is eliminated by the deletion of lysE}

To account for the undesired secretion of L-lysine in the basic strain AVA-1, the lysE gene, encoding for the lysine exporter, was deleted from the genome. For this purpose, a shortened DNA fragment, lacking 575 bp of the coding region of $l y s E$, was used to replace the native gene. Correct modification was identified by PCR analysis. Deletion of $l y s E$ positively affected the production of the desired C5-compounds in the second-generation strain C. glutamicum AVA-2. Titer (Fig. 2c) and yield (Table 1) were increased for both glutarate and 5-aminovalerate. L-Lysine excretion was fully eliminated. The excess carbon gained from exporter deletion was mostly used in favor of glutarate production. We also observed an increase in the biomass yield, as compared to the parent C. glutamicum AVA-1 strain (Table 1). Obviously, biomass formation appeared as newly arising competitor for the additionally available carbon. The specific growth rate was hardly affected by lysE deletion, whereas the specific glucose uptake rate was $30 \%$ lower (Table 1). Overall, this resulted in a decreased specific production rate for both glutarate and 5-aminovalerate, despite the increased yield (Table 1).

\section{Identification and elimination of 5-aminovalerate transaminase selectively increases the 5-aminovalerate production flux}

When aiming at the production of 5-aminovalerate, withdrawal of the product via the glutarate pathway has to be circumvented. The underlying biochemical reactions were, however not fully identified in C. glutamicum so far. For $P$. putida it is known, that two enzymes namely 5 -aminovalerate transaminase, encoded by $g a b T(\operatorname{dav} T)$, and glutarate semialdehyde dehydrogenase, encoded by $g a b D(d a v D)$ are responsible for glutarate formation from 5-aminovalerate [27]. For the glutarate semialdehyde dehydrogenase encoding gene, two potential candidates are annotated in the genome of C. glutamicum (Fig. 1). A gene annotation for the 5-aminovalerate transaminase is, however completely missing. To identify potential genes in the genome of C. glutamicum, a nucleotide BLASTX search was carried out using the gabD and gabT sequence of $P$. putida as input. From the obtained set of candidates, hits with best E-value were evaluated in more detail, considering existing annotation and genomic localization (Fig. 1). The most promising candidates were the genes NCgl0462 (gabT) and NCgl0463 ( $g a b D)$ as they show high similarity scores to the $P$. putida sequence and exhibit the same genomic organization as the P. putida genes as two adjacent open reading frames. For improving 5-aminovalerate production, we selected the gabT gene, annotated as 4-aminobutyrate aminotransferase (Fig. 1), as deletion target to immediately cut the glutarate pathway at the level of 5-aminovalerate and to avoid accumulation of the pathway intermediate glutarate semialdehyde. The coding sequence of the gene was fully deleted as validated 
a

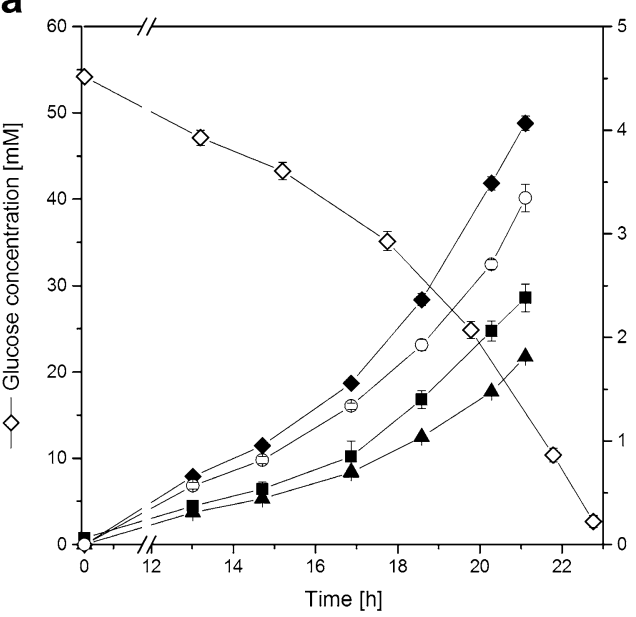

C

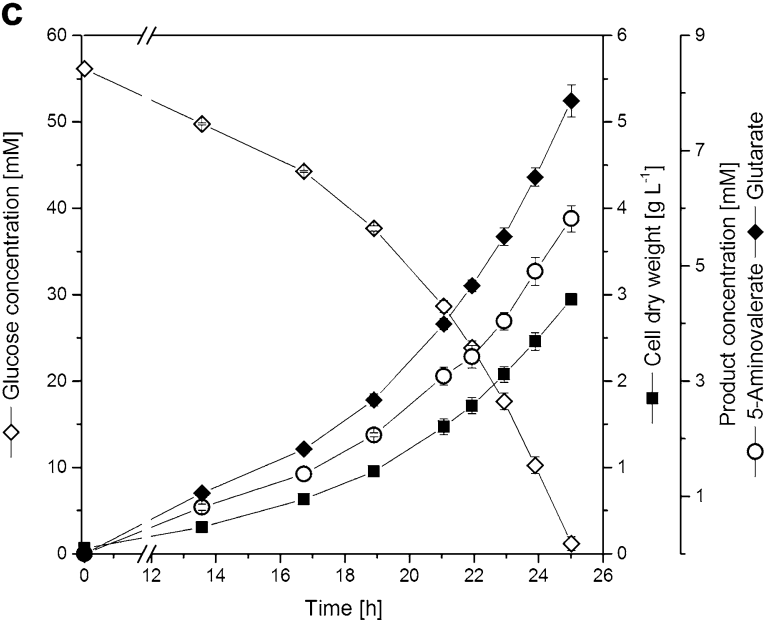

e

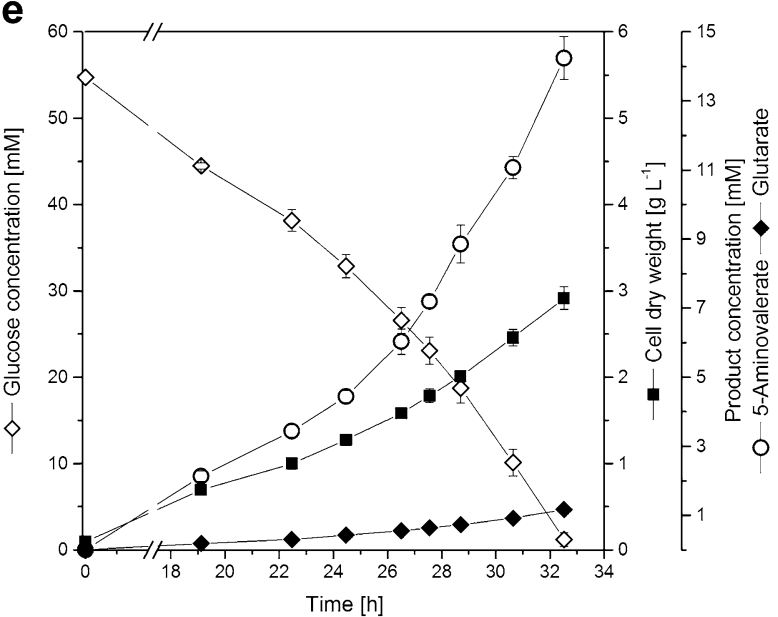

b

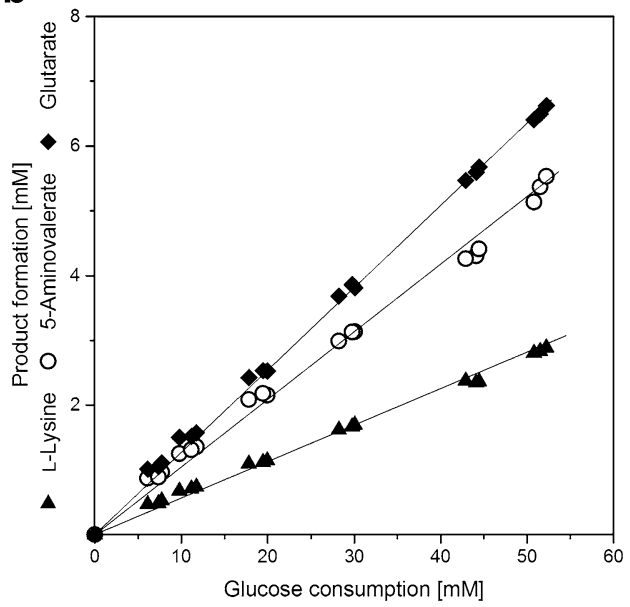

d

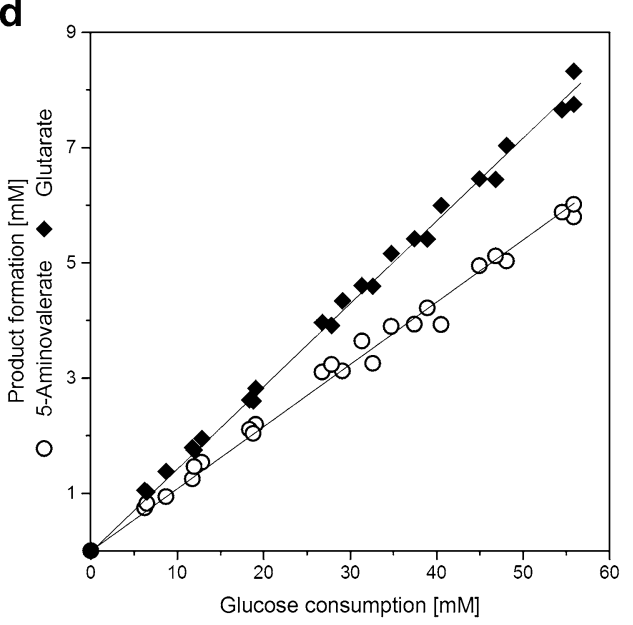

f

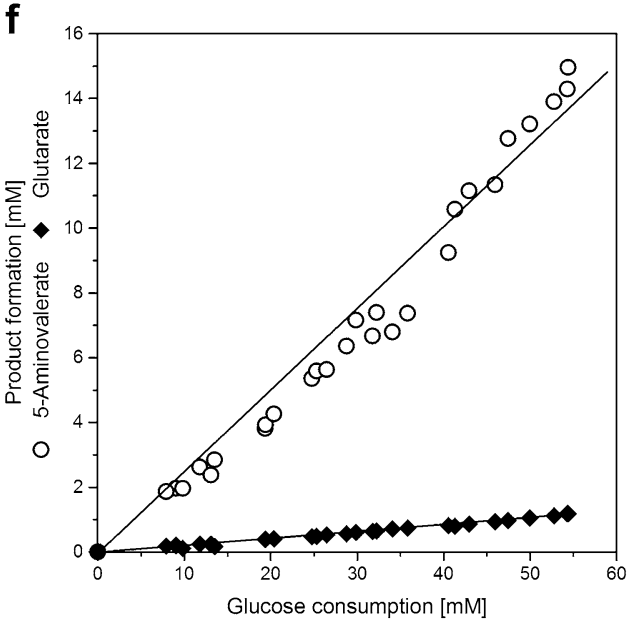

Fig. 2 Growth and production characteristics of 5-aminovalerate and glutarate producing C. glutamicum. The C. glutamicum strains AVA-1 (a, b), AVA-2 (c, d) and AVA-3 (e, f) were cultivated in shake flasks at $30^{\circ} \mathrm{C}$ in a chemically defined medium. The cultivation profiles show growth, product formation and glucose consumption over time and represent mean values and corresponding standard deviations from three biological replicates $(\mathbf{a}, \mathbf{c}, \mathbf{e})$. Yields were determined as slope from the linear correlation of glucose consumption and production formation from three biological replicates $(\mathbf{b}, \mathbf{d}, \mathbf{f})$ 
Table 1 Growth and production performance of the C. glutamicum strains AVA-1, AVA-2 and AVA-3 during batch cultivation in shake flasks using a mineral salt medium with glucose as sole carbon source

\begin{tabular}{|c|c|c|c|}
\hline & $\begin{array}{l}\text { C. glutamicum } \\
\text { AVA-1 }\end{array}$ & $\begin{array}{l}\text { C. glutamicum } \\
\text { AVA-2 }\end{array}$ & $\begin{array}{l}\text { C. glutamicum } \\
\text { AVA-3 }\end{array}$ \\
\hline \multicolumn{4}{|l|}{ Rates } \\
\hline$\mu\left[h^{-1}\right]$ & $0.22 \pm 0.04$ & $0.20 \pm 0.00$ & $0.11 \pm 0.00$ \\
\hline $\mathrm{q}_{\mathrm{s}}\left[\mathrm{mmol} \mathrm{g} \mathrm{g}^{-1} \mathrm{~h}^{-1}\right]$ & $4.59 \pm 0.70$ & $3.67 \pm 0.27$ & $2.16 \pm 0.07$ \\
\hline $\mathrm{q}_{\text {Ava }}\left[\mathrm{mmol} \mathrm{g} \mathrm{g}^{-1} \mathrm{~h}^{-1}\right]$ & $0.43 \pm 0.06$ & $0.38 \pm 0.01$ & $0.59 \pm 0.02$ \\
\hline $\mathrm{q}_{\mathrm{Glt}}\left[\mathrm{mmol} \mathrm{g}{ }^{-1} \mathrm{~h}^{-1}\right]$ & $0.57 \pm 0.07$ & $0.50 \pm 0.00$ & $0.05 \pm 0.00$ \\
\hline $\mathrm{q}_{\text {Lys }}\left[\mathrm{mmol} \mathrm{g} \mathrm{g}^{-1} \mathrm{~h}^{-1}\right]$ & $0.24 \pm 0.04$ & $0.00 \pm 0.00$ & $0.00 \pm 0.00$ \\
\hline \multicolumn{4}{|l|}{ Yields } \\
\hline$Y_{X / S}\left[\mathrm{~g} \mathrm{~mol}^{-1}\right]$ & $47.6 \pm 3.6$ & $53.9 \pm 1.0$ & $51.8 \pm 0.5$ \\
\hline $\mathrm{Y}_{\mathrm{Ava} / \mathrm{S}}\left[\mathrm{mmol} \mathrm{\textrm {mol } ^ { - 1 } ]}\right.$ & $97.6 \pm 2.0$ & $104.9 \pm 1.8$ & $274.9 \pm 2.9$ \\
\hline $\mathrm{Y}_{\mathrm{Glt} / \mathrm{S}}\left[\mathrm{mmol} \mathrm{mol}{ }^{-1}\right]$ & $123.4 \pm 2.4$ & $140.7 \pm 5.6$ & $21.8 \pm 1.4$ \\
\hline$Y_{\text {Lys } / \mathrm{S}}\left[\mathrm{mmol} \mathrm{mol}{ }^{-1}\right]$ & $52.6 \pm 0.9$ & $0.0 \pm 0.0$ & $0.0 \pm 0.0$ \\
\hline
\end{tabular}

The data represent mean values and standard deviations from three biological replicates and denote the specific rates for growth $(\mu)$, substrate uptake ( $\left.\mathrm{q}_{\mathrm{s}}\right)$, and product formation $\left(\mathrm{q}_{\mathrm{P}}\right)$. Additionally, the yield for biomass $\left(\mathrm{Y}_{\mathrm{X} / \mathrm{s}}\right)$, 5 -aminovalerate $\left(\mathrm{Y}_{\text {Ava/s }}\right)$, glutarate $\left(\mathrm{Y}_{\mathrm{Glt} / \mathrm{S}}\right)$, and L-lysine $\left(\mathrm{Y}_{\mathrm{Ly} / / \mathrm{S}}\right)$ are given

by PCR analysis, which revealed a 1347 bp-shortened DNA fragment in C. glutamicum AVA-3 as compared to the parent strain. The strategy for generating the thirdgeneration strain C. glutamicum AVA-3 proved highly beneficial. The product 5 -aminovalerate accumulated up to $14 \mathrm{mM}$ (Fig. 2e), which was more than twice as high as compared to the ancestor strains. The mutant exhibited highest yield $\left(275 \mathrm{mmol} \mathrm{mol}^{-1}\right)$ and, in particular, highest specific production rate, despite impaired growth and glucose uptake (Table 1). The latter might partly be related to intracellular accumulation of L-lysine, 5-aminovaleramid and 5-aminovalerate as response to the network perturbation at the level of LysE and GabT. Though small, a secretion flux for glutarate remained indicating residual in vivo transamination of 5 -aminovalerate. The strong decrease in the glutarate yield (Table 1), however, clearly showed that the major contributing enzyme had been eliminated by $\mathrm{NCgl} 0462$ deletion.

\section{Excellent performance of the 5 -aminovalerate-producing C. glutamicum strain AVA-3 under fed-batch conditions}

To assess the performance of the designed production strain under conditions more relevant for an industrial process, we benchmarked 5 -aminovalerate production by this strain in a fed-batch process on a glucose-molasses medium. In the initial batch phase of the fermentation, we observed exponential growth along with 5-aminovalerate production (Fig. 4a). After a process time of $15 \mathrm{~h}$, the initially supplied sugar $\left(120 \mathrm{~g} \mathrm{~L}^{-1}\right)$ was depleted and the feed phase was started. Feeding pulses were applied to maintain sugar concentration above $20 \mathrm{~g} \mathrm{~L}^{-1}$. The level of 5-aminovalerate continuously increased from $12 \mathrm{~g} \mathrm{~L}^{-1}$ at the end of the batch phase to a final titer of $28 \mathrm{~g} \mathrm{~L}^{-1}$ after $50 \mathrm{~h}$. Glutarate was concomitantly secreted and accumulated up to $7 \mathrm{~g} \mathrm{~L}^{-1}$ (Fig. 3a). Proper determination of the optical density as indicator for biomass concentration was hampered in the feed phase due to cell agglomeration and wall-associated growth. The final biomass concentration of $70 \mathrm{~g} \mathrm{~L}^{-1}$ was hence determined gravimetrically as cell dry mass from the total reactor content at the end of the process. Trehalose was the only other by-product that accumulated in noteworthy amounts $\left(7 \mathrm{~g} \mathrm{~L}^{-1}\right)$. When evaluating the efficiency for 5-aminovalerate production throughout the process phases (Fig. 3b), slightly different yields were obtained for the batch $\left(0.11 \mathrm{~g} \mathrm{~g}^{-1}\right)$ and the feed phase $\left(0.13 \mathrm{~g} \mathrm{~g}^{-1}\right)$. The glutarate yield increased by threefold in the feed phase. The space-time yield for 5-aminovalerate was maximal in the batch phase with a rate up to $0.9 \mathrm{~g} \mathrm{~L}^{-1} \mathrm{~h}^{-1}$. Over the full process time, production occurred at more than half-maximum rate $\left(0.5 \mathrm{~g} \mathrm{~L}^{-1} \mathrm{~h}^{-1}\right)$.

\section{Discussion}

In recent years, L-lysine-derived compounds, e.g. cadaverine [13, 28, 29], glutarate [19, 22, 26], 5-aminovalerate $[20,21]$ and pipecolic acid [30] have emerged as attractive platform building blocks, to establish bio-based production routes for chemicals and materials [31, 32]. This depicts an excellent possibility to employ existing L-lysine overproducers as starting point for re-engineering. Corynebacterium glutamicum is the major industrial workhorse for the production of L-lysine [1,33] andunlike P. putida [27] and E. coli [19] — it naturally misses catabolic reactions for degradation of L-lysine. L-lysine overproducing C. glutamicum strains are hence ideal metabolic chassis for establishing bio-based fermentation 

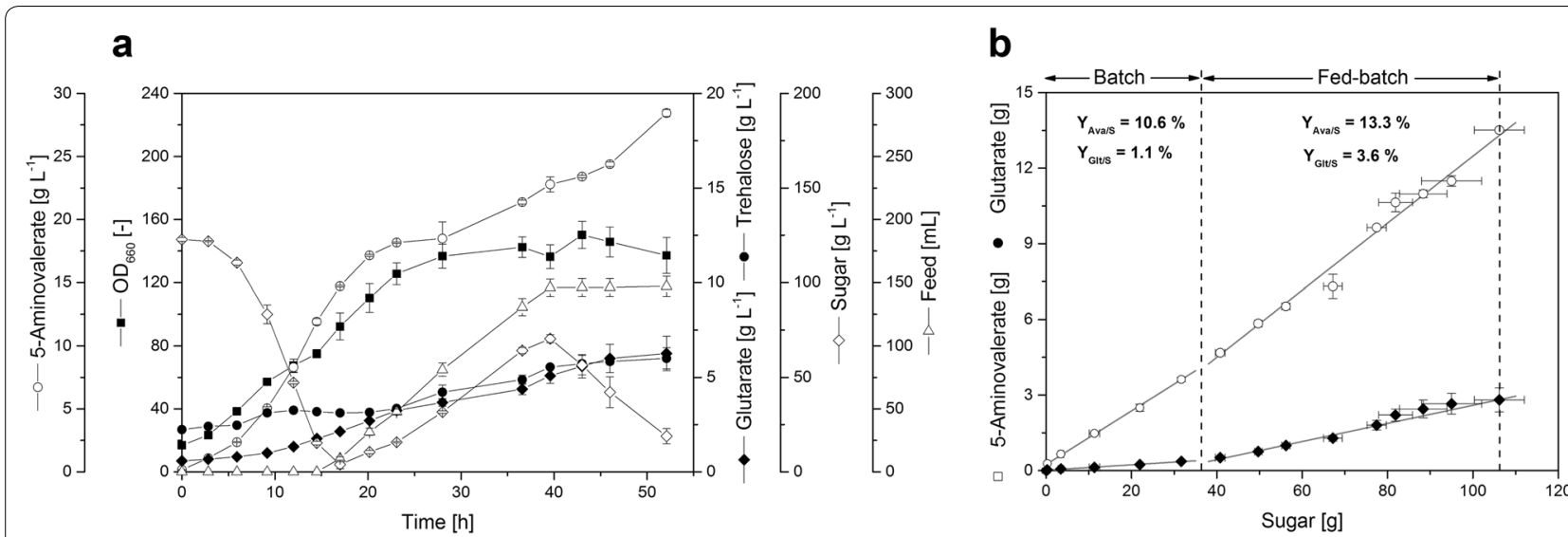

Fig. 3 Production performance of the advanced 5-aminovalerate producing strain C. glutamicum AVA-3 during fed-batch fermentation. Cultivation profile of strain AVA-3 (a), and yields for 5-aminovalerate and glutarate achieved in the different cultivation phases (b) are shown. The data represent mean values from two independent fermentation experiments

processes for these interesting compounds, as there are no side-reactions competing with the target product formation. In this work, we established a de novo production process for the carbon-5 platform chemicals 5 -aminovalerate and glutarate on basis of C. glutamicum LYS-12 [34]. These are promising building blocks for biobased polyamides and polyesters [19], when polymerized with appropriate counterparts such as caprolactame [20] and diamines [13], and beyond serve as platform chemicals [22].

\section{Expression of davBA fills the gap for de novo production of 5-aminovalerate and glutarate in C. glutamicum}

The strategy of using heterologous expression of the $P$. putida genes $\operatorname{dav} B A$ for re-programming of C. glutamicum LYS-12 for 5-aminovalerate and glutarate production proved highly valuable as more than $80 \%$ of the total production flux was drained towards the newly implemented pathway (Fig. 4). Due to the lack of L-lysine catabolic reactions, additional strain modifications, required for $E$. coli-based processes [19, 22], were obsolete. About one-third of the rechanneled carbon was secreted as 5 -aminovalerate, whereas the major fraction was further metabolized to glutarate via endogenous reactions (Fig. 4). In E. coli, production of 5-aminovalerate and glutarate specifically relied on heterologous expression of the $\operatorname{dav} A B$ cluster (5-aminovalerate) or a combined expression of the davBA-davDT ( $g a b D T$ ) clusters (glutarate) as, in contrast to C. glutamicum, endogenous genes for davDT are obviously missing [19, 20, 22]. Despite pure production of either of these compounds, E. coli reached maximal yields of $71 \mathrm{mmol} \mathrm{mol}^{-1}$ for 5 -aminovalerate and $68 \mathrm{mmol} \mathrm{mol}^{-1}$ for glutarate in a de novo process [19], which is even far below the performance of the basic AVA-1 strain (Table 1). The different production pattern for both species might be related to differences concerning re-uptake of 5-aminovalerate. E. coli efficiently converts externally added 5-aminovalerate into glutarate, when the $\operatorname{davBA}$ and $\operatorname{davDT}$ (gabDT) gene clusters from $P$. putida are concomitantly expressed [19]. The obviously active import system for 5 -aminovalerate in E. coli can thus explain that there is no mixed production of 5-aminovalerate and glutarate $[19,22]$. The constant production characteristics of our novel strains (Fig. 2), however, show that once 5 -aminovalerate is secreted, there is no re-import and further conversion to glutarate. In addition, we could not observe any glutarate formation in C. glutamicum LYS-12 when 5-aminovalerate was supplied to the medium. This is attributed to the lack of an active 5-aminovalerate uptake system under the tested conditions. Efficient product secretion without re-uptake-as found in this study for C. glutamicum-is highly desirable and might even become crucial to establish commercially feasible processes [35-37]. The genome-based engineering approach ensured strain stability as previously proven for manifold genetic manipulations of C. glutamicum [38-42]. Overall, production of the target metabolites and the remaining L-lysine production in the AVA-1 strain nicely summed up to the L-lysine production of the parent strain [34]. We took this finding as good indicator that no other by-products arose in noteworthy amounts, as previously shown for cadaverine-producing C. glutamicum [10, 11].

\section{5 -aminovalerate production is limited by the in vivo activity of the heterologous pathway}

The secretion of L-lysine in the AVA-1 strain revealed limitations in the in vivo activity of the downstream 


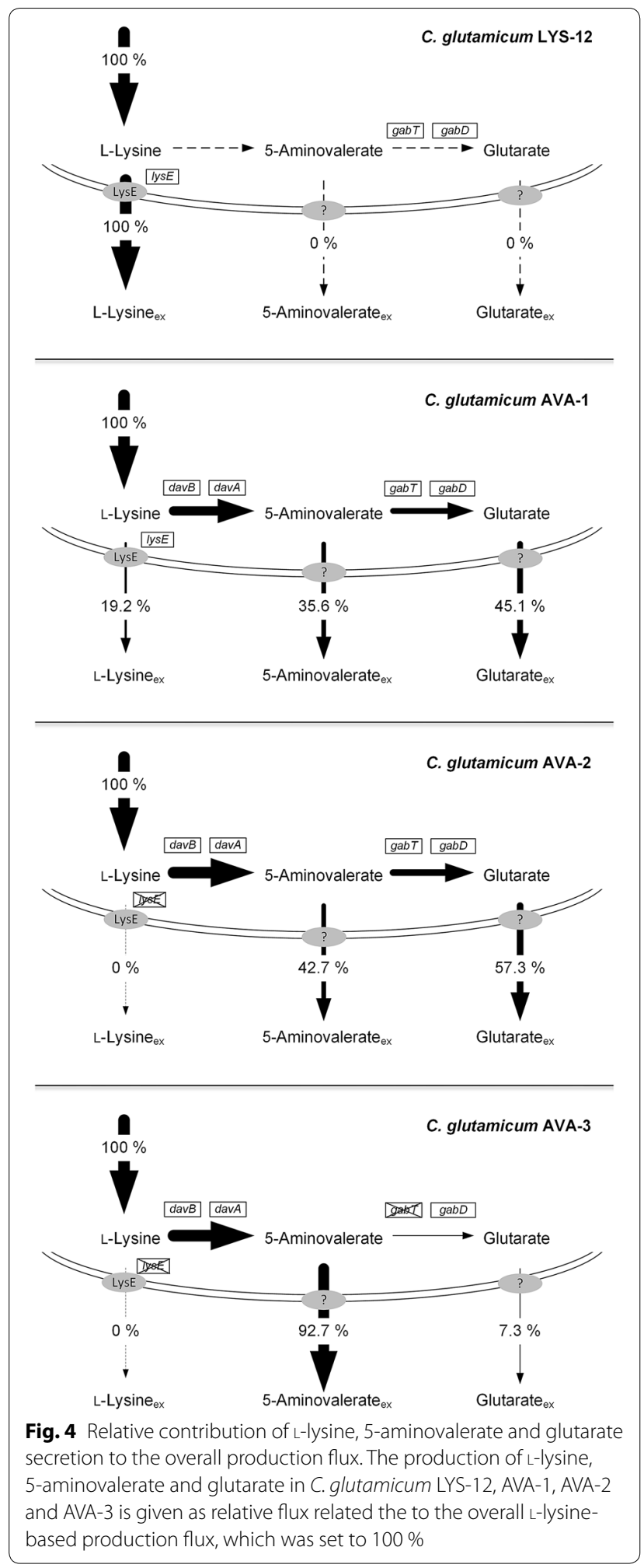

5-aminovalerate pathway. The newly implemented pathway operated less efficiently than the cadaverine pathway, previously established in C. glutamicum, which fully converted L-lysine into cadaverine by the heterologously implemented lysine decarboxylase [10]. Intracellular L-lysine accumulation in the AVA-1 strain was, however, sufficient to induce expression of the L-lysine exporter [43, 44]. Consequently, the exporter LysE competed with lysine monooxygenase for intracellular L-lysine as substrate, a phenomenon similarly found previously for L-lysine-derived cadaverine production, whereby the cadaverine export protein competed with cytosolic acetyl-transferase reaction that formed $\mathrm{N}$-acetyl-cadaverine $[10,11]$. We hence had a closer look at the enzyme activity of lysine monooxygenase and 5-aminovaleramidase. In vitro assays with crude cell extract revealed that the lysine consumption rate, reflecting lysine monooxygenase activity, was two times higher than the production rate of 5-aminovalerate, reflecting 5-aminovaleramidase activity. Expression of both enzymes from the designed operon was obviously not perfectly balanced. For enzymatic production of 5-aminovalerate, however, it was recently shown, that a 1:1 ratio of both enzymes is required for optimal production [21]. On basis of the in vitro activity, the bottleneck of the 5-aminovalerate pathway could on a first glance be assigned to 5-aminovaleramidase. The initial step catalyzed by lysine monooxygenase is, however, massively feedback inhibited by 5 -aminovaleramide, 5 -aminovalerate, and glutarate at levels of $5 \mathrm{mM}$ [27], likely resulting in a substantially reduced in vivo activity. Moreover, from enzyme activity measurements, carried out in closed tubes, we have additional indication that lysine monooxygenase can become limiting, when oxygen supply is insufficient. In in vitro studies with limited oxygen supply, identical rates for lysine consumption and 5-aminovalerate production were determined $\left(0.56 \pm 0.01 \mathrm{mmol} \mathrm{L}^{-1} \mathrm{~h}^{-1}\right)$. We hence cannot clearly attribute the bottleneck specifically to one of the enzymes and/or an imbalanced expression thereof. Elimination of LysE activity was therefore most straightforward to avoid loss of the pathway precursor L-lysine. Lacking any secretion system for L-lysine, the additionally available carbon in the AVA-2 strain was partly used in favor of 5-aminovalerate and glutarate formation, and partly supports biomass production, as similarly found recently for ectoine producing C. glutamicum [45]. Despite the higher yields, the specific production rates were not increased as the in vivo activity of the heterologous pathway remained a limiting factor. The rates were actually lower than in the parent strain (Table 1), as the overall fitness $\left(\mu, \mathrm{q}_{\mathrm{S}}\right)$ of the AVA-2 strain was slightly impaired. Further improvement of the strain performance can thus be expected from higher $\operatorname{davBA}$ gene expression. Moreover, removal of feedback inhibition of lysine monooxygenase is a highly desirable, though challenging task for future strain optimization. 
The glutarate pathway is the major competitor for 5 -aminovalerate production

The obtained production pattern clearly indicated that the endogenous transaminase reaction of the glutarate pathway is dominating over the 5 -aminovalerate export. Deletion of the putative transaminase GabT in the AVA-3 strain successfully redirected the production flux to 5-aminovalerate, though glutarate production was not fully eliminated. Obviously, C. glutamicum possesses more than one gene and enzyme, responsible for 5 -aminovalerate transamination. It is interesting to note that $P$. putida, which can naturally degrade L-lysine via the 5-aminovalerate/glutarate pathway, only possesses a single $g a b T$ gene variant, the lack of which prevents growth on L-lysine as sole carbon source [46]. Additional deletion of further gene candidates for $g a b T$ and $g a b D$ (Fig. 1) appears most straightforward to further diminish glutarate formation in the C. glutamicum AVA-3 strain. However, only few is known about their actual function, leaving a certain risk of undesired side effects upon deletion. As alternative strategy, the enhancement of the 5 -aminovalerate export could drive a more efficient product secretion. Indeed, transport processes are a major issue of industrial processes and thus often addressed in the production hosts for improving production of e.g. cadaverine [12, 47], amorphadiene [48], L-lysine [49] and L-arginine [50]. In light of the strong feedback inhibition of lysine monooxygenase, the secretion efficiency appears even more relevant. Similar to E. coli [19], the transport mechanisms for 5-aminovalerate and associated proteins are not yet known for C. glutamicum. The secretory capacity of C. glutamicum for non-natural compounds is, however, admirable as demonstrated in recent years for the production of ectoine [45], cadaverine [12], putrescine [8], and $\gamma$-amino butyric acid [51]. As shown for cadaverine [12], export is thereby not necessarily linked to a unique and specific transporter. There are likely transporter families with promiscuous secretory activity for structurally related metabolites, which might be of help for identification.

\section{High-cell density fermentation reveals excellent production performance}

To take benefit from high cell density and the generally improved production performance [34, 45], the best 5 -aminovalerate producer was investigated during fed-batch operation. C. glutamicum AVA-3 produced $28 \mathrm{~g} \mathrm{~L}^{-1}$ of 5 -aminovalerate within only $50 \mathrm{~h}$, which is the highest titer and productivity described so far for de novo production of this compound [19, 22, 26]. The maximal space-time yield of about $0.9 \mathrm{~g} \mathrm{~L}^{-1} \mathrm{~h}^{-1}$ was even within the range of bio-conversion processes directly producing 5-aminovalerate from L-lysine [19-22]. De novo production as described here obviously benefits over such bio-transformation process, as production can be conducted as one-step process directly from cheap raw material, regularly applied for industrial fermentation [24, 25, 52]. In contrast, biotransformation requires successive production steps for the supply of the biocatalyst, e.g. whole cells or purified enzymes, and a subsequent conversion step for product formation. Moreover, it strictly relies on the pathway precursor L-lysine, additionally being produced by fermentation, requiring subsequent purification. In this regard, de novo production is clearly more flexible, related to the broad natural substrate spectrum of C. glutamicum and additional engineering of assimilation routes for non-natural carbon sources [53, 54]. Depending on price and availability, alternative renewable feedstocks $[29,40,55]$ or carboncontaining waste streams from industry $[54,56]$ might become more attractive, and could hence be used for production.

\section{Conclusion}

In this work, we established C. glutamicum as production platform for the polyamide building blocks 5 -aminovalerate and glutarate through genetically stable genome manipulation. Following the strategy of heterologous engineering of the 5-aminovalerate pathway from $P$. putida $[19,22,26]$, combined with additional modifications that targeted by-product formation, we generated a strain with the highest de novo production performance concerning titer, yield and productivity. With the remaining issues on the in vivo activity of the $\operatorname{dav} B A$ pathway, 5-aminovalerate export and glutarate production, we can immediately identify future engineering targets towards strain improvement. Further optimization can be expected applying systems metabolic engineering to unravel and circumvent additional and less obvious bottlenecks through iterative rounds of strain analysis, design and genetic engineering. Similar titer, yield and productivity as already achieved for L-lysine [34] and cadaverine $[13,57]$ production thus appear feasible to leverage performance of 5-aminovalerate to industrial efficiency. Moreover, the AVA-2 strain already builds an ideal basis for generating glutarate overproducing C. glutamicum strains.

\section{Methods}

\section{Microorganisms and plasmids}

In the present work, the ATCC 13032-derived L-lysineoverproducing C. glutamicum strain LYS-12 [34] was used as host to establish 5-aminovalerate and glutarate production. Reconstruction of the 5-aminovalerate pathway relied on the $\operatorname{dav} B A$ genes, encoding lysine monooxygenase and 5-aminovaleramidase from $P$. 
putida KT2440. Amplification of transformation vectors on basis of the integrative plasmid pClik int $s a c B[10,58]$ was carried out in E. coli strains DH5 $\alpha$ and NM522 (Invitrogen, Carlsbad, CA, USA) [34]. All strains and plasmids employed in this study are listed in Table 2.

\section{Molecular design and genetic engineering}

For molecular strain, plasmid and primer design, the Clone Manager Professional 9 (Sci-Ed Software, Denver, USA) was used. For sequence similarity search towards identification of $g a b T$ and $g a b D$ candidates in the genome of C. glutamicum, the corresponding gene sequences from P. putida (PP_0214, gabT, davT and PP_0213, gabD, davD) were BLASTed (BLASTX, http://www.genome. jp/tools/blast/) against the C. glutamicum genome, deposited at KEGG (http://www.genome.jp/kegg/). The genetic construct for genome-based integration of the davBA gene cluster from $P$. putida KT2440 comprised (i) $500 \mathrm{bp}$-sized flanking regions as homologous recombination sites for the bioD locus (NCgl2516), (ii) a 200 bpsized DNA fragment of the promotor of the structural tuf gene (NCgl0480), and (iii) the biosynthetic genes $\operatorname{davB}$ (PP_0383) and davA (PP_0382), which were separated by a 20-bp sized ribosomal binding site as intergenic region (Fig. 1). The putative gabT gene (NCgl0462) was fully deleted from the genome. All DNA fragments were amplified by PCR $(2 \times$ Phusion Flash PCR Master Mix, Thermo Scientific, Waltham, MA, USA; peQSTAR, PEQLAB Biotechnology GmbH, Erlangen, Germany) from genomic DNA of C. glutamicum ATCC13032 and P. putida KT2440, respectively, with sequence specific primers (Table 3). DNA fragment and vector assembly was carried out by the method of Gibson [59]. The reaction mixture contained $157.5 \mathrm{mM}$ Tris- $\mathrm{HCl}(\mathrm{pH} 7.5)$,

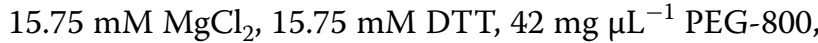
$0.6{\mathrm{mg} \mu \mathrm{L}^{-1}}^{\mathrm{N} A D}, 25 \mathrm{mU} \mu \mathrm{L}^{-1}$ Phusion ${ }^{\mathrm{TM}}$ High-Fidelity DNA Polymerase (Thermo Fisher Scientific, Rochester, New York, USA), $7.5 \mathrm{mU} \mu \mathrm{L}^{-1} \mathrm{~T} 5$ exonuclease (Epicentre, Madison, USA), $4 \mathrm{U}_{\mu} \mathrm{L}^{-1}$ Taq Ligase (Thermo Fisher Scientific, Rochester, New York, USA), each $0.3 \mathrm{mM}$ dNTPs. Prior to this, the vector was linearized via restriction with BamHI (FastDigest ${ }^{\circledR}$, Thermo Fisher Scientific, St. Leon-Roth, Germany). Vector amplification in the $E$. coli strains DH5 $\alpha$ and NM522, purification of plasmid DNA, and its transformation into E. coli and C. glutamicum strains were performed as described previously [39]. PCR and sequence analysis (GATC Biotech AG, Konstanz, Germany) were used for plasmid and strain validation. Deletion of the $l y s E$-gene encoding the L-lysine exporter of C. glutamicum was conducted as described previously [12].

\section{Batch cultivation in shake flasks}

Corynebacterium glutamicum was grown in baffled shake flasks with $10 \%$ filling volume at $30{ }^{\circ} \mathrm{C}$ and $230 \mathrm{rpm}$ on an orbital shaker (Multitron, Infors AG, Bottmingen, Switzerland; $5 \mathrm{~cm}$ diameter). The cultivation procedure involved one pre-culture in complex medium (37 $\left.\mathrm{g} \mathrm{L}^{-1} \mathrm{BHI}\right)$ followed by another pre-cultivation in minimal medium to adapt cells to the medium conditions of the main cultivation [60]. The main cultivation was carried out as triplicate in a chemically defined mineral

Table 2 Description of the C. glutamicum strains and plasmids used in the present work for the heterologous production of 5-aminovalerate and glutarate

Description

Reference

Strain

C. glutamicum LYS-12

C. glutamicum AVA-1

C. glutamicum AVA-2

C. glutamicum AVA-3

Plasmids

pTC

pClik int sacB

pClik int sacB tuf $f_{p}$ $\operatorname{dav} B A$

pClik int sacB $\triangle y s E$

pClik int sacB $\triangle$ gabT

Lysine-hyperproducing strain with 12 genome-based modifications

[34]

LYS-12 + genome-based integration of the P. putida genes davB (PP_0383) and davA (PP_0382) encoding lysine monooxygenase and aminovaleramide amidase, into the bioD gene locus (NCgl2516), encoding dithiobiotin synthetase

AVA-1 + deletion of lysE gene (NCgl1214), encoding the lysine exporter

This work

AVA-2 + deletion of putative gabT gene (NCgl0462), encoding 5-aminovalerate transaminase

This work

Expression vector for DNA-methyltransferase of C. glutamicum, ORI for E. coli and tetracycline resistance as selection marker. Used in E. coli NM522 to add the C. glutamicum-specific DNA-methylation pattern to the integrative transformation vector

Integrative transformation vector for C. glutamicum with MCS, ORI for E. coli, and Kan ${ }^{\mathrm{R}}$ and sacB as selection markers

Integrative transformation vector for genome-based implementation of davBA genes from P. putida KT2440 into This work the bioD locus of C. glutamicum

Integrative transformation vector for deletion of the lysine exporter lysE

[34]

[58]

Integrative transformation vector for deletion of the 5-aminovalerate transaminase gene gabT
[12]

This work 
Table 3 Description of primers that were used in the present work for genome-based integration of tuf-promoter controlled davBA genes from $P$. putida in the bioD locus $\left(P_{\mathrm{davBA}-1} \mathbf{P R}_{\mathrm{davBA}-10)}\right.$ and for deletion of the gabT gene (PR ${ }_{\mathrm{gabT}-1}{ }^{-}$ $\mathrm{PR}_{\text {gabT_}} 4$ ) in C. glutamicum

\begin{tabular}{|c|c|c|}
\hline No. & Sequence & AT $\left[{ }^{\circ} \mathrm{C}\right]$ \\
\hline $\mathrm{PR}_{\mathrm{davBA} A} 1$ & CTGCGTTAATTAACAATTGGTAAGCAATGGCCTACAACCAGAC & 59 \\
\hline $\mathrm{PR}_{\text {davBA}}{ }_{2}$ & CATTCGCAGGGTAACGGCCAGGTTTATTTCCCTTTAACTGCAGC & 57 \\
\hline $\mathrm{PR}_{\text {davBA_} 3}$ & CAGTTAAAGGGAAATAAACCTGGCCGTTACCCTGCGAATG & 62 \\
\hline $\mathrm{PR}_{\text {davBA}} 4$ & TGGCGGTTCTTCTTGTTCATTGTATGTCCTCCTGGACTTCGTGGTG & 64 \\
\hline $\mathrm{PR}_{\text {davBA_} 5}$ & GAAGTCCAGGAGGACATACAATGAACAAGAAGAACCGCCACCCCGC & 68 \\
\hline$P R_{\text {davBA_}} 6$ & GCGCATTGTATGTCCTCCTGGACTTCTCAATCCGCCAGGGCGATCGG & 66 \\
\hline $\mathrm{PR}_{\text {davBA_}} 7$ & CGATCGCCCTGGCGGATTGAGAAGTCCAGGAGGACATACAATGCGCATCGCTCTGTACCAGG & 64 \\
\hline $\mathrm{PR}_{\text {davBA_} 8} 8$ & CGAAGGCACGGTGTTCACGATCAGCCTTTACGCAGGTGCAG & 62 \\
\hline $\mathrm{PR}_{\text {davBA_}} 9$ & TGCACCTGCGTAAAGGCTGATCGTGAACACCGTGCCTTCG & 62 \\
\hline PR $R_{\text {davBA_10 }}$ & AATCCCGGGTCTAGAGGATCACGCATGAGTGTGCTTGTGGAA & 62 \\
\hline $\mathrm{PR}_{\text {gabT_} 1} 1$ & CTGCGTTAATTAACAATTGGCGCTGGAGGTGATCGAGATAAATG & 59 \\
\hline $\mathrm{PR}_{\text {gap } T-2}$ & CTGGGAAGGTCAAAGACACTGGTTCCTCCTGTGAGGTGAGATAC & 59 \\
\hline $\mathrm{PR}_{\text {gabT_}} 3$ & CTCACCTCACAGGAGGAACCAGTGTCTTTGACCTTCCCAG & 56 \\
\hline $\mathrm{PR}_{\text {gabT_}} 4$ & AATCCCGGGTCTAGAGGATCCAAAGACGGAGGCGATGATC & 57 \\
\hline
\end{tabular}

salt medium with glucose as the carbon source [61]. The medium contained: (A) $500 \mathrm{~mL}$ salt solution $(1 \mathrm{~g} \mathrm{NaCl}$, $55 \mathrm{mg} \mathrm{MgCl}_{2} \cdot 7 \mathrm{H}_{2} \mathrm{O}$ and $\left.200 \mathrm{mg} \mathrm{CaCl}\right)$, (B) $100 \mathrm{~mL}$ substrate solution (100 $\mathrm{g} \mathrm{L}^{-1}$ glucose), (C) $100 \mathrm{~mL}$ buffer solution (2 M potassium phosphate, $\mathrm{pH} 7.8$ ), (D) $100 \mathrm{~mL}$ solution B (150 g L $\left.{ }^{-1}\left(\mathrm{NH}_{4}\right)_{2} \mathrm{SO}_{4}, \mathrm{pH} 7.0\right)$, (E) $20 \mathrm{~mL}$ vitamin solution $\left(25 \mathrm{mg} \mathrm{L}^{-1}\right.$ biotin, $50 \mathrm{mg} \mathrm{L}^{-1}$ thiamine $\cdot \mathrm{HCl}$ and $50 \mathrm{mg} \mathrm{L}^{-1}$ pantothenic acid), (F) $10 \mathrm{~mL} \mathrm{FeSO}_{4}$-solution (2 $\mathrm{g} \mathrm{L}^{-1} \mathrm{FeSO}_{4}$, pH 1.0), (G) $10 \mathrm{~mL} 100 \times$ trace elements [62] and (H) $1 \mathrm{~mL}$ DHB-solution $\left(30 \mathrm{mg} \mathrm{mL}^{-1}\right.$ of 3,4-dihydroxybenzoic acid in $0.3 \mathrm{M} \mathrm{NaOH}$ ) adjusted to $1 \mathrm{~L}$ with milliQ. Solutions were separately sterilized by autoclaving $(\mathrm{A}-\mathrm{D})$ or by filtration $(\mathrm{E}-\mathrm{H})$. The different medium compounds were combined at room temperature freshly before use.

\section{Fed-batch cultivation in stirred tank bioreactors}

The production performance of the optimized 5-aminovalerate-producer C. glutamicum AVA-3 was evaluated in a fed-batch process. This was carried out in a complex molasses-based medium, containing per liter: $72.4 \mathrm{~g}$ beet molasses, $35 \mathrm{~mL}$ corn steep liquor, $40 \mathrm{~g}\left(\mathrm{NH}_{4}\right)_{2} \mathrm{SO}_{4}, 99 \mathrm{~g}$ glucose $\cdot \mathrm{H}_{2} \mathrm{O}, 250 \mu \mathrm{L} \mathrm{H}_{3} \mathrm{PO}_{4}(85 \%), 11 \mathrm{mg} \mathrm{FeSO} \cdot 7 \mathrm{H}_{2} \mathrm{O}$, $10 \mathrm{mg}$ citrate, $9 \mathrm{mg}$ biotin, $17.5 \mathrm{mg}$ thiamine $\cdot \mathrm{HCl}, 60 \mathrm{mg}$ pantothenic acid Ca-salt, $18 \mathrm{mg}$ nicotinamid, $6 \mathrm{mg}$ ribo-

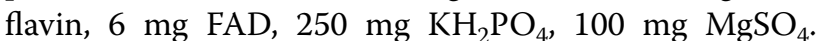
The initial batch was started in a volume of $300 \mathrm{~mL}$ in a $1000 \mathrm{~mL}$ bioreactor (SR0700ODLS, DASGIP AG, Jülich, Germany) and inoculated with cells as previously described [13]. Dosing of the feed $\left(650 \mathrm{~g} \mathrm{~L}^{-1}\right.$ glucose $\cdot \mathrm{H}_{2} \mathrm{O}$, $162.5 \mathrm{~g} \mathrm{~L}^{-1}$ beet molasses, $40 \mathrm{~g} \mathrm{~L}^{-1}\left(\mathrm{NH}_{4}\right)_{2} \mathrm{SO}_{4}, 6 \mathrm{mg} \mathrm{L}^{-1}$ riboflavin, $6 \mathrm{mg} \mathrm{L}^{-1} \mathrm{FAD}$ ) was initiated when the sugar concentration dropped below $20 \mathrm{~g} \mathrm{~L}^{-1}$ and adjusted to maintain glucose concentration constant above $20 \mathrm{~g} \mathrm{~L}^{-1}$. The cultivation temperature was kept constant at $30{ }^{\circ} \mathrm{C}$ via the CWD4 bioblock (DASGIP AG, Jülich, Germany). The $\mathrm{pH}$ and the $\mathrm{pO}_{2}$ level were monitored online with a pH electrode (Mettler Toledo, Giessen, Germany) and a $\mathrm{pO}_{2}$ electrode (Hamilton, Höchst, Germany). The $\mathrm{pH}$ was kept constant at $6.9 \pm 0.1$ by automated addition of $25 \%$ $\mathrm{NH}_{4} \mathrm{OH}$ (MP8 pump system, Eppendorf, Hamburg, Germany). The dissolved oxygen level was maintained at saturation above $30 \%$ by variation of the stirrer speed and the aeration rate. Data acquisition and process operations were controlled by the DAGIP control software (DASGIP AG, Jülich, Germany).

\section{Substrate and product quantification}

Amino acids and 5-aminovalerate were quantified by HPLC, using $\alpha$-aminobutyric acid as internal standard [63] with a modified gradient ( 0 min: $70 \%$ eluent $A$; 14 min: $56 \%$ eluent A; 14.5 min: $0 \%$ eluent A; 16.5 min: $0 \%$ eluent A; 17 min: $70 \%$ eluent A; 19 min: $70 \%$ eluent A). Samples from fed-batch fermentation were additionally diluted with MilliQ water prior to dilution with the internal standard to account for the detector limit $(<1.5 \mathrm{mM})$. Quantification of glucose and organic acids was carried out by isocratic HPLC (Agilent 1260 Infinity Series, Waldbronn, Germany) comprising a degasser (G4225A), an autosampler (G1329B) including thermostat (G1330B), an isocratic pump (G1310B), a column oven (G1316C), and a refraction index (RI) detector (G1362A). Separation was conducted on an Aminex HPX-87H column $(300 \times 7.8 \mathrm{~mm}$; Bio-Rad, München, 
Germany) at $55^{\circ} \mathrm{C}$. As mobile phase $3.5 \mathrm{mM} \mathrm{H}_{2} \mathrm{SO}_{4}$ was used at a flow rate of $0.8 \mathrm{~mL} \mathrm{~min}^{-1}$. The injection volume was $20 \mu \mathrm{L}$. For sugar analysis of supernatant samples from fed-batch fermentation, a Metacarb 87C column $(300 \times 7.8 \mathrm{~mm}$; Agilent, Darmstadt, Germany) with Metacarb $87 \mathrm{C}$ guard column $(50 \times 7.8 \mathrm{~mm}$; Agilent, Darmstadt, Germany) and additional Micro-Guard De-Ashing Refill Cartridges (Bio-Rad, München, Germany) was used at $85{ }^{\circ} \mathrm{C}$ with demineralized water as mobile phase at a flow rate of $0.4 \mathrm{~mL} \mathrm{~min}{ }^{-1}$. If appropriate, samples were diluted prior to analysis. Refraction index was used for detection. Concentration of cell dry mass (CDM) was calculated from the optical density using a correlation factor of $\mathrm{CDM}[\mathrm{g} / \mathrm{L}]=0.32 \times \mathrm{OD}_{660}$. This was determined as described previously [61] for the here used UV-1600PC spectrophotometer (VWR, Hannover, Germany).

\section{Determination of enzyme activity}

Crude cell extracts were prepared from exponentially growing cells by mechanical cell disruption. Cultivation and harvest procedure was carried out as previously described [29]. Aliquots of $1 \mathrm{~mL}$ cell suspension were then transferred into FastPrep ${ }^{\circledR}-24$ vials (MP Biomedicals, Illkirch-Graffenstaden, France) containing silica beads $(\varnothing 0.1 \mathrm{~mm})$ and cell disruption was carried out in $2 \times 30$ s cycles at $5000 \mathrm{rpm}$ (Precellys ${ }^{\circledR}-24$, PeqLab, Hannover, Germany) including $1 \mathrm{~min}$ cooling pauses on ice. Removal of cell debris and protein quantification was performed as previously described [61]. The protocol for subsequent quantification of the conversion rate of L-lysine into 5-aminovalerate, comprising the lumped activity of lysine monooxygenase and 5-aminovaleramide amidase, was based on previous protocols $[19,21]$. The final reaction mixture of $5 \mathrm{~mL}$ contained $100 \mathrm{mM}$ phosphate buffer (pH 7.5), $15 \mathrm{mM}$ L-lysine, and $50 \mu \mathrm{L} \mathrm{mL}^{-1}$ of crude cell extract $\left(0.5 \mathrm{mg} \mathrm{mL}^{-1}\right.$ of protein). Incubation was carried out at $30^{\circ} \mathrm{C}$ and $230 \mathrm{rpm}$ on an orbital shaker (Multitron, Infors AG, Bottmingen, Switzerland) in $50 \mathrm{~mL}$ baffled shake flasks. Samples were regularly taken and thermally inactivated $\left(5 \mathrm{~min}, 100{ }^{\circ} \mathrm{C}\right.$, Thermomixer F1.5, Eppendorf, Hamburg, Germany). L-lysine consumption and 5-aminovalerate formation were quantified by HPLC as given above. Negative controls were conducted without the addition of crude cell extract and L-lysine, respectively. Moreover, the crude cell extract of the parent strain C. glutamicum LYS-12 was analyzed to account for potential non-DavBA associated enzymatic reactions.

\footnotetext{
Abbreviations

Ava: 5-aminovalerate; AKG: a-ketoglutarate; bioD: encoding gene of dithiobiotin synthetase; davA: encoding gene of aminovaleramide amidase; davB: encoding gene of lysine monooxygenase; gapT: encoding gene of
}

5-aminovalerate transaminase; gabD: encoding gene of glutarate semialdehyde dehydrogenase; Glt: glutarate; Glu: glutamate; Lys: L-lysine; LysE, lysE: lysine exporter and corresponding gene; MCS: multiple cloning site; ORI: origin of replication; PCR: polymerase chain reaction; sacB: encoding gene of levansucrase from Bacillus subtilis; tuf: encoding gene of elongation factor tu.

\section{Authors' contributions}

CR constructed the strains and conducted cultivation experiments in shake flasks. GG and MK carried out fed-batch fermentation and analytics. JB performed strain and experimental design, and the enzyme activity studies. JB and CW conceived and structured the work, assessed the data and wrote the manuscript. All authors read and approved the final manuscript.

\section{Acknowledgements}

CW and MK acknowledge the financial support from the BMBF-Grant "Bio2Nylon" (No. 03V0757).

\section{Competing interests}

The authors declare that they have no competing interests.

\section{Availability of data and materials}

The dataset(s) supporting the conclusions of this article are all included within the article.

\section{Ethics approval and consent to participate}

Not applicable. The manuscript does not contain data collected from humans or animals.

\section{Funding}

CW and MK acknowledge the financial support from the BMBF-Grant "Bio2Nylon" (No. 03V0757). The funding body did not contribute to the design of the study, data collection, analysis, and interpretation, or writing of the manuscript.

Received: 29 July 2016 Accepted: 2 September 2016

Published online: 13 September 2016

\section{References}

1. Becker J, Wittmann C. Advanced biotechnology: metabolically engineered cells for the bio-based production of chemicals and fuels, materials, and health-care products. Angew Chem Int Ed Engl. 2015;54:3328-50.

2. Becker J, Lange A, Fabarius J, Wittmann C. Top value platform chemicals: bio-based production of organic acids. Curr Opin Biotechnol. 2015;36:168-75.

3. Becker J, Reinefeld J, Stellmacher R, Schäfer R, Lange A, Meyer H, Lalk M, Zelder O, von Abendroth G, Schröder H, et al. Systems-wide analysis and engineering of metabolic pathway fluxes in bio-succinate producing Basfia succiniciproducens. Biotechnol Bioeng. 2013;1 10:3013-23.

4. Inui M, Murakami S, Okino S, Kawaguchi H, Vertes AA, Yukawa H. Metabolic analysis of Corynebacterium glutamicum during lactate and succinate productions under oxygen deprivation conditions. J Mol Microbiol Biotechnol. 2004;7:182-96.

5. Okino S, Noburyu R, Suda M, Jojima T, Inui M, Yukawa H. An efficient succinic acid production process in a metabolically engineered Corynebacterium glutamicum strain. Appl Microbiol Biotechnol. 2008;81:459-64.

6. Okino S, Suda M, Fujikura K, Inui M, Yukawa H. Production of D-lactic acid by Corynebacterium glutamicum under oxygen deprivation. Appl Microbiol Biotechnol. 2008;78:449-54.

7. Harder BJ, Bettenbrock K, Klamt S. Model-based metabolic engineering enables high yield itaconic acid production by Escherichia coli. Metab Eng. 2016;38:29-37.

8. Schneider J, Wendisch VF. Putrescine production by engineered Corynebacterium glutamicum. Appl Microbiol Biotechnol. 2010;88:859-68.

9. Qian ZG, Xia XX, Lee SY. Metabolic engineering of Escherichia coli for the production of putrescine: a four carbon diamine. Biotechnol Bioeng. 2009; 104:651-62 
10. Kind S, Jeong WK, Schröder H, Wittmann C. Systems-wide metabolic pathway engineering in Corynebacterium glutamicum for bio-based production of diaminopentane. Metab Eng. 2010;12:341-51.

11. Kind S, Jeong WK, Schröder H, Zelder O, Wittmann C. Identification and elimination of the competing $\mathrm{N}$-acetyldiaminopentane pathway for improved production of diaminopentane by Corynebacterium glutamicum. Appl Environ Microbiol. 2010;76:5175-80.

12. Kind S, Kreye S, Wittmann C. Metabolic engineering of cellular transport for overproduction of the platform chemical 1,5-diaminopentane in Corynebacterium glutamicum. Metab Eng. 2011;13:617-27.

13. Kind S, Neubauer S, Becker J, Yamamoto M, Völkert M, Abendroth GV, Zelder O, Wittmann C. From zero to hero-production of bio-based nylon from renewable resources using engineered Corynebacterium glutamicum. Metab Eng. 2014;25:113-23.

14. Qian ZG, Xia XX, Lee SY. Metabolic engineering of Escherichia coli for the production of cadaverine: a five carbon diamine. Biotechnol Bioeng. 2011;108:93-103.

15. Altaras NE, Cameron DC. Metabolic engineering of a 1,2-propanediol pathway in Escherichia coli. Appl Environ Microbiol. 1999;65:1 180-5.

16. Celinska E. Debottlenecking the 1,3-propanediol pathway by metabolic engineering. Biotechnol Adv. 2010;28:519-30.

17. Rados D, Carvalho AL, Wieschalka S, Neves AR, Blombach B, Eikmanns BJ, Santos H. Engineering Corynebacterium glutamicum for the production of 2,3-butanediol. Microb Cell Fact. 2015;14:171.

18. Yim H, Haselbeck R, Niu W, Pujol-Baxley C, Burgard A, Boldt J, Khandurina J, Trawick JD, Osterhout RE, Stephen R, et al. Metabolic engineering of Escherichia coli for direct production of 1,4-butanediol. Nat Chem Biol. 2011;7:445-52.

19. Adkins J, Jordan J, Nielsen DR. Engineering Escherichia coli for renewable production of the 5-carbon polyamide building-blocks 5-aminovalerate and glutarate. Biotechnol Bioeng. 2013;110:1726-34.

20. Park SJ, Oh YH, Noh W, Kim HY, Shin JH, Lee EG, Lee S, David Y, Baylon MG, Song BK, et al. High-level conversion of L-lysine into 5-aminovalerate that can be used for nylon 6,5 synthesis. Biotechnol J. 2014;9:1322-8.

21. Liu P, Zhang H, Lv M, Hu M, Li Z, Gao C, Xu P, Ma C. Enzymatic production of 5-aminovalerate from L-lysine using L-lysine monooxygenase and 5-aminovaleramide amidohydrolase. Scientific reports. 2014;4:5657.

22. Park SJ, Kim EY, Noh W, Park HM, Oh YH, Lee SH, Song BK, Jegal J, Lee SY. Metabolic engineering of Escherichia coli for the production of 5-aminovalerate and glutarate as $C_{5}$ platform chemicals. Metab Eng. 2013;16:42-7.

23. Kirchner $\mathrm{O}$, Tauch $\mathrm{A}$. Tools for genetic engineering in the amino acidproducing bacterium Corynebacterium glutamicum. J Biotechnol. 2003;104:287-99.

24. Kelle R, Hermann T, Bathe B. L-Lysine production. In: Eggeling L, Bott M, editors. Handbook of Corynebacterium glutamicum. Boca Raton: CRC Press; 2005. p. 465-88.

25. Eggeling L, Bott M. A giant market and a powerful metabolism: L-lysine provided by Corynebacterium glutamicum. Appl Microbiol Biotechnol. 2015;99(8):3387-94.

26. Shin JH, Park SJ, Lee SY. Metabolic engineering of Corynebacteruim glutamicum for production of 5-aminovaleric acid and glutaric acid as C5 platform chemicals. In: 16th European Congress on Biotechnology. New Biotechnol. 2014;31:S162. doi:10.1016/..nbt.2014.05.2021.

27. Vandecasteele JP, Hermann M. Regulation of a catabolic pathway. Lysine degradation in Pseudomonas putida. Eur J Biochem. 1972;31:80-5.

28. Mimitsuka T, Sawai H, Hatsu M, Yamada K. Metabolic engineering of Corynebacterium glutamicum for cadaverine fermentation. Biosci Biotechnol Biochem. 2007;71:2130-5.

29. Buschke N, Schröder H, Wittmann C. Metabolic engineering of Corynebacterium glutamicum for production of 1,5-diaminopentane from hemicellulose. Biotechnol J. 2011;6:306-17.

30. Perez-Garcia F, Peters-Wendisch P, Wendisch VF. Engineering Corynebacterium glutamicum for fast production of L-lysine and L-pipecolic acid. Appl Microbiol Biotechnol. 2016;100(18):8075-90.

31. Kind S, Wittmann C. Bio-based production of the platform chemical 1,5-diaminopentane. Appl Microbiol Biotechnol. 2011;91:1287-96.

32. Jang YS, Kim B, Shin JH, Choi YJ, Choi S, Song CW, Lee J, Park HG, Lee SY. Bio-based production of C2-C6 platform chemicals. Biotechnol Bioeng. 2012;109:2437-59.
33. Becker J, Wittmann C. Systems and synthetic metabolic engineering for amino acid production - the heartbeat of industrial strain development. Curr Opin Biotechnol. 2012;23:718-26.

34. Becker J, Zelder O, Haefner S, Schröder H, Wittmann C. From zero to hero-design-based systems metabolic engineering of Corynebacterium glutamicum for L-lysine production. Metab Eng. 2011;13:159-68.

35. Ikeda M. L-tryptophan production. In: Eggeling L, Bott M, editors. Handbook of Corynebacterium glutamicum. Boca Raton: CRC Press; 2005. p. 489-509.

36. Ikeda M. Towards bacterial strains overproducing L-tryptophan and other aromatics by metabolic engineering. Appl Microbiol Biotechnol. 2006;69:615-26.

37. Becker J, Kind S, Wittmann C. Systems metabolic engineering of Corynebacterium glutamicum for biobased production of chemicals, materials and fuels. In: Wittmann C, Lee SY, editors. Systems metabolic engineering. Dordrecht Heidelberg New York London: Springer; 2012. p. $152-91$.

38. Bolten CJ, Schröder H, Dickschat J, Wittmann C. Towards methionine overproduction in Corynebacterium glutamicum-methanethiol and dimethyldisulfide as reduced sulfur sources. J Microbiol Biotechnol. 2010;20:1196-203.

39. Becker J, Buschke N, Bücker R, Wittmann C. Systems level engineering of Corynebacterium glutamicum - reprogramming translational efficiency for superior production. Eng Lif Sci. 2010;10:430-8.

40. Neuner A, Heinzle E. Mixed glucose and lactate uptake by Corynebacterium glutamicum through metabolic engineering. Biotechnol J. 2011;6:318-29.

41. Becker J, Klopprogge C, Herold A, Zelder O, Bolten CJ, Wittmann C. Metabolic flux engineering of L-lysine production in Corynebacterium glutamicum-over expression and modification of G6P dehydrogenase. J Biotechnol. 2007;132:99-109.

42. Becker J, Klopprogge C, Wittmann C. Metabolic responses to pyruvate kinase deletion in lysine producing Corynebacterium glutamicum. Microb Cell Fact. 2008;7:8.

43. Krömer JO, Sorgenfrei O, Klopprogge K, Heinzle E, Wittmann C. In-depth profiling of lysine-producing Corynebacterium glutamicum by combined analysis of the transcriptome, metabolome, and fluxome. J Bacteriol. 2004;186:1769-84.

44. Bellmann A, Vrljic M, Patek M, Sahm H, Krämer R, Eggeling L. Expression control and specificity of the basic amino acid exporter LysE of Corynebacterium glutamicum. Microbiology. 2001;147:1765-74.

45. Becker J, Schäfer R, Kohlstedt M, Harder BJ, Borchert NS, Stöveken N, Bremer E, Wittmann C. Systems metabolic engineering of Corynebacterium glutamicum for production of the chemical chaperone ectoine. Microb Cell Fact. 2013;12:110.

46. Revelles O, Espinosa-Urgel M, Fuhrer T, Sauer U, Ramos JL. Multiple and interconnected pathways for L-lysine catabolism in Pseudomonas putida KT2440. J Bacteriol. 2005;187:7500-10.

47. Li M, Li D, Huang Y, Liu M, Wang H, Tang Q, Lu F. Improving the secretion of cadaverine in Corynebacterium glutamicum by cadaverine-lysine antiporter. J Ind Microbiol Biotechnol. 2014;41:701-9.

48. Zhang C, Chen X, Stephanopoulos G, Too HP. Efflux transporter engineering markedly improves amorphadiene production in Escherichia coli. Biotechnol Bioeng. 2016;113(8):1755-63.

49. Vrljic M, Sahm H, Eggeling L. A new type of transporter with a new type of cellular function: L-lysine export from Corynebacterium glutamicum. Mol Microbiol. 1996;22:815-26.

50. Lubitz D, Jorge JM, Perez-Garcia F, Taniguchi H, Wendisch VF. Roles of export genes cgmA and lysE for the production of $\mathrm{I}$-arginine and L-citrulline by Corynebacterium glutamicum. Appl Microbiol Biotechnol. 2016. doi:10.1007/s00253-016-7695-1.

51. Shi F, Li Y. Synthesis of gamma-aminobutyric acid by expressing Lactobacillus brevis-derived glutamate decarboxylase in the Corynebacterium glutamicum strain ATCC 13032. Biotechnol Lett. 2011;33:2469-74.

52. Wittmann C, Becker J. The L-lysine story. From metabolic pathways to industrial production. In: Wendisch VF, editor. Amino Acid biosynthesis - pathways, regulation and metabolic engineering. Berlin Heidelberg: Springer; 2007. p. 40-68.

53. Becker J, Wittmann C. Bio-based production of chemicals, materials and fuels-Corynebacterium glutamicum as versatile cell factory. Curr Opin Biotechnol. 2012;23:631-40. 
54. Buschke N, Schäfer R, Becker J, Wittmann C. Metabolic engineering of industrial platform microorganisms for biorefinery applications-optimization of substrate spectrum and process robustness by rational and evolutive strategies. Bioresour Technol. 2013;135:544-54.

55. Kawaguchi $H$, Sasaki M, Vertes AA, Inui M, Yukawa H. Engineering of an L-arabinose metabolic pathway in Corynebacterium glutamicum. Appl Microbiol Biotechnol. 2008;77:1053-62.

56. Meiswinkel TM, Rittmann D, Lindner SN, Wendisch VF. Crude glycerolbased production of amino acids and putrescine by Corynebacterium glutamicum. Bioresour Technol. 2013;145:254-8.

57. Buschke N, Becker J, Schäfer R, Kiefer P, Biedendieck R, Wittmann C. Systems metabolic engineering of xylose-utilizing Corynebacterium glutamicum for production of 1,5-diaminopentane. Biotechnol J. 2013;8:557-70.

58. Becker J, Klopprogge C, Zelder O, Heinzle E, Wittmann C. Amplified expression of fructose 1,6-bisphosphatase in Corynebacterium glutamicum increases in vivo flux through the pentose phosphate pathway and lysine production on different carbon sources. Appl Environ Microbiol. 2005;71:8587-96

59. Gibson DG, Young L, Chuang RY, Venter JC, Hutchison CA 3rd, Smith HO Enzymatic assembly of DNA molecules up to several hundred kilobases. Nat Methods. 2009;6:343-5.

60. Kind S, Becker J, Wittmann C. Increased lysine production by flux coupling of the tricarboxylic acid cycle and the lysine biosynthetic pathwaymetabolic engineering of the availability of succinyl-CoA in Corynebacterium glutamicum. Metab Eng. 2013;15:184-95.

61. Becker J, Klopprogge C, Schröder H, Wittmann C. Metabolic engineering of the tricarboxylic acid cycle for improved lysine production by Corynebacterium glutamicum. Appl Environ Microbiol. 2009;75:7866-9.

62. Vallino JJ, Stephanopoulos G. Metabolic flux distributions in Corynebacterium glutamicum during growth and lysine overproduction. Biotechnol Bioeng. 1993;41:633-46.

63. Krömer JO, Fritz M, Heinzle E, Wittmann C. In vivo quantification of intracellular amino acids and intermediates of the methionine pathway in Corynebacterium glutamicum. Anal Biochem. 2005:340:171-3.

\section{Submit your next manuscript to BioMed Central and we will help you at every step:}

- We accept pre-submission inquiries

- Our selector tool helps you to find the most relevant journal

- We provide round the clock customer support

- Convenient online submission

- Thorough peer review

- Inclusion in PubMed and all major indexing services

- Maximum visibility for your research

Submit your manuscript at www.biomedcentral com/submit
() Biomed Central 